\title{
A Comparative Study for Understanding the Problems Faced by Male and Female Undergraduate Students in Acquisition of Speaking Skill Competence, While Learning English as a Foreign Language in Karachi, Pakistan
}

\author{
Muhammad Ali Shaikh ${ }^{1}$, Nadia Saeed ${ }^{2}$, Subhash Guriro ${ }^{3}$, Stephen John ${ }^{4}$ \& Zahid Hussain Sathito ${ }^{5}$ \\ ${ }^{1}$ Department of Media and Communication Studies, Sindh Madressatul Islam University, Karachi, Pakistan \\ ${ }^{2}$ School of Foreign Languages, Central China Normal University, Wuhan, China \\ ${ }^{3}$ Department of Social Development, Sindh Madressatul Islam University, Karachi, Pakistan \\ ${ }^{4}$ Department of Education, Sindh Madessatul Islam University, Karachi, Pakistan \\ ${ }^{5}$ Department of Teacher Education, Shah Latif University, Khairpur Sindh, Pakistan \\ Correspondence: Stephen John, Department of Education, Sindh Madessatul Islam University, Karachi, Pakistan. \\ E-mail: sjohn@smiu.edu.pk
}

Received: December 21, 2019 Accepted: January 23, 2020 Online Published: February 13, 2020

doi:10.5539/ijel.v10n2p266

URL: https://doi.org/10.5539/ijel.v10n2p266

\begin{abstract}
Pakistan is one of the developing countries where English is taught from primary to graduation level as a compulsory subject, but it is observed and quoted by a number of researchers in their research that the EFL learners are found weak in one of the basic language learning skill i.e., speaking. Keeping in view this issue of learners this research study was conducted to investigate the types of difficulties the male and female learners of EFL face in acquisition of speaking skills competence and to get their suggestions, which they expect from teachers or authorities to do in their endeavors of improving speaking skill competence in overcoming the difficulties faced by them. The sample consisting of 120 undergraduate students from 10 universities was selected. A questionnaire having 10 close-ended and 05 open-ended items was distributed among the participants. The analysis of quantitative data suggests that comparatively males give more importance to skill for success in career than female, moreover they are more hesitant than females because of lack of confidence, afraid of mistakes and of being criticized, etc. while analysis of qualitative data reveals that only $27 \%$ participants are satisfied by their speaking skills competence, $51 \%$ were unable to reason what is important for mastering speaking skills, $20 \%$ said, they are unable to speak because of lack of confidence, $38 \%$ feel speaking skill is the most difficult skill, while $35 \%$ favored classroom activities for improving speaking skill competence. On the basis of findings from the suggestions of the participants, it is concluded that if teachers arrange classroom activities, then there will be a positive impact on students' confidence as activities will improve the speaking skill competence of the learners.
\end{abstract}

Keywords: acquisition, competency, English as a foreign language, undergraduate students

\section{Introduction}

\subsection{Statement of Problem}

It is commonly observed that students find it difficult to speak English though in Pakistan, they are taught English as a compulsory subject from lower to higher level of education. In some educational institutions, students are supposed to take it a compulsory course. Zhang (2009) argued that speaking remains the most difficult skill to master for majority EFL learners, and they are still incompetent in communicating orally in English. They are found hesitant to respond to the queries in English though they are very proficient in their own or mother language. English is taught in almost all countries of the world as a foreign or second language and students learn to read and write just to understand the contents of the books and pass their examinations but when they have to express their ideas orally, they find it very difficult.

\subsection{Relevant Literature}

The English language has the prestige to be the international language (Osborn, 2008). Among nations, it serves as 
a lingua franca. Even in those countries, it is spoken, learned and understood where it is not a native language. Educationists, scientists, and business personnel use it in their daily routine for communication and students use it for advance studies. Internet that is connecting people around the globe, there again medium of communication is the English language, moreover, we cannot use software and other useful applications unless we know English (Lucas, 2011). Commenting on the importance of the English language, Ibrahim (2013) writes that English is the language of science and research. Researchers in different parts of the world conduct and compile their researches in English. These researches are read and benefited by a number of readers while the stuff that is written in other languages is read by limited people. Patil (2008) stresses the importance of the English language and says it is used in different parts of the world for communication of messages, thoughts, and ideas among different people or communities of the world.

It is an ultimate reality, that a language is learned by speaking and in this exercise, a group of people needs to involve themselves, they exchange words in different contexts, this exchange of words helps in improving language, moreover, selection of words should be done very carefully because negligence on speaker's part may result in communication breakdown or learning gap. Keeping in view this diligence, speaking skills are given more importance. According to Hancock (2012), speaking skills are important for people in a number of ways because a person with good speaking power can communicate more effectively and clearly, his ideas are perceived by others without any misinterpretation. Goh (2017) says, speaking is productive when we exchange our thoughts and argue with others, we come up with something new. Speaking skill is an interpersonal skill which helps us to have a good image among colleagues/people. Baily (2005) writes, "a good speaker always depends entirely on his/her art of persuasion through speech". A good speaker always communicates considering the audience and uses those words and phrases that are generally in common use, always avoids irrelevant arguments and focuses on the topic. An effective speaker is an organized person whose purpose is to convey the message without confusing the listeners (Tarigan, 1987, cited in Musaddat, 2008).

Acquisition of speaking competence in English as a foreign language is indeed a complex process, a learner with knowledge of grammar and good vocabulary often fails to speak target language confidently. In order to master speaking skills, the learners must get training in dealing tactfully. Burnkart (1998) comments that learners of a target language should focus on pronunciation, grammar, and vocabulary. They should know the correct use of linguistic elements and must learn what to speak and when to speak in a situation they encounter. Moreover, for the acquisition of effective speaking skills, a learner of a target language must have awareness of the culture of the native speakers, this will help them a lot to speak appropriately and efficiently. When we acquaint ourselves with the culture of native speakers, we begin to learn to read facial expressions, body gestures and other ways they use to communicate. Communication becomes more effective when we have an understanding of non-verbal clues used by the native speakers of a target language. The acquisition of speaking competence in a foreign language is very complicated (Hinkel, 2005, cited in Nazara, 2011). Yusuf and Sewoyo (1997) state that undergraduate students should be proficient in four skills i.e., listening, speaking, reading and writing as they study English as a compulsory course in their academic programs. At the same time, other researchers have highlighted that the linguistic competencies of undergraduate are very less. But on the other hand, it is embarrassing that in Asia particularly in Pakistan, even after learning English from lower to a higher level for many years, learners of English cannot use it confidently. As communicative approach emphasizes the use of language in real-life situations and social interactions, therefore it is widely adopted by educational institutions in Asia from lower to a higher level but results are still far from satisfactory. Some researchers have highlighted that the language trainers/teachers do not demonstrate a positive attitude towards the teaching and training of EFL learners. Language is a skill that needs to be taught by well-trained language experts who can plan and implement good and effective activities for their learners, who can understand what the learners need to know and how can they be groomed to be effective speakers of the target language, moreover they need to become role model for their students. Huda (2019) quotes that the English language spoken proficiency of teachers is also low, as only $4.8 \%$ of English language teachers use English during classroom teaching and instructions. Therefore, the acquisition of speaking competence is a shared problem for teachers and students. A study conducted by Alwasilah (cited in Kasim, 2003) reveals that the linguistic competence of students from school to university level is not satisfactory. Undergraduate students are unable to speak when they encounter any situation, especially where they need to take part in some conversation in English. While sitting in the classroom, they avoid raising their queries out of hesitation, as they lack confidence. Even the students of the English department demonstrate the same attitude. This attitude deprives them of a number of learning opportunities during their academic career and ultimately affecting their professional growth. They remain in a limited circle and can't avail of opportunities to explore new things in their lives. The difficulties in the acquisition of speaking competence in EFL are the result of some drawbacks that need to be overcome. The learners do not find any word or expression as per situation, therefore, 
they prefer to stay silent. They are over conscious about accuracy while this is an accepted fact that first comes fluency than accuracy. They have a fear of being criticized by their classmates and sometimes by their teachers. Taiqin (2015) reported the same causes for difficulties the learners of EFL experience in mastering speaking skills. He added that fear of losing self-esteem is one of the biggest hurdles faced by EFL learners. The difficulties that learners face in their endeavor to learn speaking can be placed into two categories namely linguistics and nonlinguistic. Brown (2011) has pointed out the difficulties the learners come across during the process of speaking skills acquisition, according to him learners need to practice speaking by uttering clusters rather than memorizing words and their meanings. They can't become fluent speakers unless they start this practice i.e., uttering phrases rather than just words. The English language has some contractions i.e., can't for cannot, shouldn't for should not, haven't for have not, lets for letting us, etc., EFL learners must know and practice such contractions. Speaking triggers our thinking process, at initial stage learners think and speak but after a couple of days or weeks practice, they become fluent in speech. They learn to overcome their fear, anxiety, mistakes, and errors. Learners also need to learn stress and intonation pattern which is also one of the most important aspects of language learning. A native speaker of the English language uses several interjections or fillers like "well", "I mean", "Uhm" etc. These interjections assist in understanding the situation and learners also learn the words/expressions like native speakers, this helps EFL learners to grasp speaking competence. In addition to grammar and vocabulary, learners should learn language structures, common idioms, and phrasal verbs. Ur (1996) explains four factors that make speaking difficult for second or foreign language students. According to him, unlike reading, writing and listening activities, speaking is more demanding. For speaking skills competence EFL learners need a platform where they may have exposure to the audience, they often try to say things in a foreign language in the classroom, worried about making mistakes, having fear of criticism, or losing face, or simply shy of attention. Another issue that they have nothing to say, they have no motive to express themselves beyond the guilty feelings that they should speak. He further says they use mother language for communication in the classroom, as this will be unnatural to them to communicate in a foreign language. Lastly, he says, low or uneven participation hinders in their way of speaking competence.

\subsection{Objectives}

The objective of this research study was to investigate the problems/difficulties faced by the learners in speaking English and to get their opinions for bringing change in the methods of teaching the English language which is ultimately affecting their speaking competence.

\subsection{Research Questions}

Following research questions were raised to solve the query:

- What type of difficulties are faced by EFL learning while communicating orally in English?

- How can they overcome those difficulties?

\section{Methodology}

Both quantitative and qualitative approaches were adopted to solve the problem. A questionnaire consisting of fifteen (15) close-ended questions and five (05) ended questions was served to undergraduate students who used to study English from lower to the present level. Initially, the questionnaire was piloted to ten (10) boys' and girls' students with the purpose to check the reliability, while for face and content validity the questionnaire was shared with the experts. Then few of the items were amended or dropped before finally data collection.

The population of this research study was undergraduate students of public and private universities three (03) each of Karachi, Pakistan. Both genders were given equal opportunities and questionnaires were distributed to randomly selected students twenty (20) each university ( 10 each boy \& girls) who showed a willingness to participate in the study. The total sample of both participants' boys and girls was one hundred and twenty (120) undergraduate students.

\section{Data Analysis, Discussion, and Conclusions}

\subsection{Quantitative Data Analysis}

The collected quantitative data was analyzed using SPSS, Mean, Standard Deviation, and Standard Error of Mean of the responses against each item were calculated. The detail is as under: 
Table 1. Quantitative data analysis

\begin{tabular}{|c|c|c|c|c|c|c|}
\hline $\begin{array}{l}\text { Item } \\
\text { No. }\end{array}$ & Items & Gender & $\mathbf{N}$ & Mean & $\begin{array}{l}\text { Std. } \\
\text { Deviation }\end{array}$ & $\begin{array}{l}\text { Std. Error } \\
\text { of Mean }\end{array}$ \\
\hline \multirow[t]{2}{*}{1} & \multirow[t]{2}{*}{ Speaking skills are important for success in a career. } & Male & 60 & 3.60 & .493 & .057 \\
\hline & & Female & 60 & 3.76 & .489 & .056 \\
\hline \multirow[t]{2}{*}{2} & \multirow[t]{2}{*}{ Speaking skills have a great effect on personal life. } & Male & 60 & 3.03 & .753 & .087 \\
\hline & & Female & 60 & 3.45 & .622 & .072 \\
\hline \multirow[t]{2}{*}{3} & \multirow{2}{*}{$\begin{array}{l}\text { It is not easy for learners learning English as a foreign language } \\
\text { to speak English. }\end{array}$} & Male & 60 & 2.27 & 1.319 & .152 \\
\hline & & Female & 60 & 2.24 & .956 & .110 \\
\hline \multirow[t]{2}{*}{4} & \multirow[t]{2}{*}{ Speaking skills are complex and difficult. } & Male & 60 & 2.04 & .979 & .113 \\
\hline & & Female & 60 & 2.04 & 1.179 & .136 \\
\hline \multirow[t]{2}{*}{5} & \multirow{2}{*}{$\begin{array}{l}\text { The student remains hesitant to speak English as they lack } \\
\text { confidence. }\end{array}$} & Male & 60 & 3.03 & .838 & .097 \\
\hline & & Female & 60 & 3.08 & .749 & .086 \\
\hline \multirow[t]{2}{*}{6} & \multirow{2}{*}{$\begin{array}{l}\text { Students do not speak English as they are afraid of making } \\
\text { mistakes, and of being criticized. }\end{array}$} & Male & 60 & 3.08 & .926 & .107 \\
\hline & & Female & 60 & 3.05 & .957 & .111 \\
\hline \multirow[t]{2}{*}{7} & \multirow{2}{*}{$\begin{array}{l}\text { Students do not speak because they don't know how to } \\
\text { pronounce words. }\end{array}$} & Male & 60 & 2.16 & 1.053 & .122 \\
\hline & & Female & 60 & 2.59 & .988 & .114 \\
\hline \multirow[t]{2}{*}{8} & \multirow[t]{2}{*}{ Students do not speak because they have a limited vocabulary. } & Male & 60 & 2.52 & 1.245 & .144 \\
\hline & & Female & 60 & 2.67 & 1.031 & .119 \\
\hline \multirow[t]{2}{*}{9} & \multirow[t]{2}{*}{ Grammar is a must for learning. } & Male & 60 & 2.76 & 1.217 & .141 \\
\hline & & Female & 60 & 2.68 & 1.117 & .129 \\
\hline \multirow[t]{2}{*}{10} & \multirow{2}{*}{$\begin{array}{l}\text { Students must know language structures, phrasal verbs, and } \\
\text { idioms of English. }\end{array}$} & Male & 60 & 3.16 & .931 & .107 \\
\hline & & Female & 60 & 2.44 & 1.276 & .147 \\
\hline \multirow[t]{2}{*}{11} & \multirow{2}{*}{$\begin{array}{l}\text { Students do speak English because they are not motivated to } \\
\text { speak. }\end{array}$} & Male & 60 & 2.72 & 1.008 & .116 \\
\hline & & Female & 60 & 2.61 & 1.229 & .142 \\
\hline \multirow[t]{2}{*}{12} & \multirow[t]{2}{*}{ Students do not have ideas to speak } & Male & 60 & 2.49 & .906 & .105 \\
\hline & & Female & 60 & 2.09 & 1.141 & .132 \\
\hline \multirow[t]{2}{*}{13} & \multirow{2}{*}{$\begin{array}{l}\text { Students are unable to communicate in English, as mostly they } \\
\text { use mother language for communication. }\end{array}$} & Male & 60 & 2.71 & 1.194 & .138 \\
\hline & & Female & 60 & 2.39 & 1.335 & .154 \\
\hline \multirow[t]{2}{*}{14} & \multirow{2}{*}{$\begin{array}{l}\text { Teachers use English for instructions and communication with } \\
\text { students. }\end{array}$} & Male & 60 & 2.85 & .766 & .088 \\
\hline & & Female & 60 & 2.56 & 1.093 & .126 \\
\hline \multirow[t]{2}{*}{15} & \multirow{2}{*}{$\begin{array}{l}\text { Teachers supervise when students are communicating in English } \\
\text { with one another during class. }\end{array}$} & Male & 60 & 3.05 & .695 & .080 \\
\hline & & Female & 60 & 2.36 & 1.035 & .120 \\
\hline
\end{tabular}

For both males and females, the means are approximately the same, which is an indication that data are probably normally distributed, while, the low standard error suggests that if we repeat the study, we would likely get the same results. The spread of scores in items 1, 2, 3, 5, 6, 8 and 9 (as shown by S.D) is a little high for males than it is for females, suggesting that males give more importance to speaking skills for success in career. They feel that speaking skill has great effects on their personal life and it is not easy for them to learn English speaking skills. They remain hesitant to speak English as they lack confidence, are afraid of making mistakes, and of being criticized. They also avoid to speak because they don't know how to pronounce the words, have limited vocabulary and feel grammar learning is a must for them. While the spread of scores in Item 4, 10, 11, 12, 13, 14 \& 15 (as shown by S.D) is high for females than it is for males, suggesting that females find speaking skills more complex and difficult. They feel students must know language structures, phrasal verbs as well as idioms of English. They need motivation for Speaking English, having no idea to speak, as they mostly use mother language for communication. They agreed that teachers use English for communication in the class for instructions, and also supervise whether students communicate in English with one another during class or not.

\subsection{Qualitative Data Analysis}

The responses of the participants against the five (05) open-ended questions were sorted labeled and quantified. The labeled quantifies responses are as under:

Item-1 The students were asked that "To what extent you are satisfied with your knowledge and speaking skills of English as a foreign language?" The responses were labeled as 'No Proper Response', Don't Know, 'Not', 'Somehow' and 'Satisfied'. 22\% respondents were having such response which was reflecting that they were not able to understand the question, 3.7\% respondents used confusing phrase 'Don't Know', $20 \%$ respondents declared that they are not satisfied by their knowledge of English language and speaking skills competence, 25\% respondents were somehow satisfied, while $27 \%$ respondents used the word 'Yes' they are satisfied by the knowledge and speaking skills competence. 
Item-2 The second question posed was "In your opinion, what is the most important thing we need to master speaking skills?" $51 \%$ respondents did not give proper answer as required, $20 \%$ respondents expressed that the way of talking or in other words the accent, $20 \%$ respondents said, confidence is the most important thing we need to have better speaking skills, $5.5 \%$ were favored vocabulary, $1.8 \%$ recommended learning of grammatical rules, while $1.8 \%$ pointed out that listening is the most important thing which could help in improving speaking skills.

Item-3 The respondents were asked, "is speaking skill the most difficult skill?" $22 \%$ respondents were unable to give proper answer, $7.4 \%$ were having opinion if learners do practice they can improve this skill, $1.8 \%$ suggested that interest could improve this skill, 3.7\% expressed that motivation can play its role in learning and improving this skill, $38 \%$ disclosed that its difficult to cope speaking skill, while only $27 \%$ said, it's not difficult for them.

Item-4 The respondents were asked to share the shortcoming of English language classes. 20\% respondents expressed that the teachers are unable to build confidence of the learners, $8 \%$ unable to improve vocabulary of the learners, $11.76 \%$ said that the teachers are unable to provide more knowledge to the ELT learners, $5.8 \%$ disclosed that the university is not arranging extra classes for those who are weak in speaking skill and the same number of respondents also said that the interest of the learners also hinder in the way of improving speaking competence, $14.2 \%$ shared that vocabulary is the main issue behind this skill, while $20.5 \%$ respondents answered in such a way which indicates that they were not able to understand the question asked

Item-5 Through this question, the respondents were to give suggestion which could help in overcoming the mentioned shortcomings. $5.6 \%$ of respondents suggested that students must be provided reading material, which will help in improving the speaking skills, $16.9 \%$ said that teachers need to motivate the students, $35 \%$ favored classroom activities, while $22 \%$ of respondents gave no suggestion.

\section{Recommendations}

On the basis of conclusions drawn from the analysis of data, the following are the recommendations:

Language teachers should be active instructors; they must be able to motivate students to take part in speaking activities. They must be innovative and must have the ability to change the culture of the classroom. For many teachers, a classroom is just a place where they have to make students listen to them. But now researchers have revealed that passive classrooms indicate no learning, while active/noisy classroom indicates that learning is taking place. They must be able to develop interest among students to learn to speak happily. They should arrange effective activities for students that may help them in their cognitive development and they may learn to deal with their day to day activities without any difficulty/hesitation. They should motivate the learners not to lose their hearts if they are unable to speak in a few attempts, as speaking is a skill that can be learned after repeated practice. They should be patient with the mistakes/errors made by the students.

\section{References}

Bailey, K. M. (2005). Practical English Language Teaching: Speaking. New York: McGraw-Hill.

Bashiruddin, A. (2003). Learning English and learning to teach English: The Case of Two Teachers of English in Pakistan. Unpublished Doctorate Dissertation, University of Toronto, Canada.

Brown, H. D. (2011). Teaching by Principles: An Interactive Approach to Language Pedagogy. New York: Longman.

Burnkart, G. S. (1998). Spoken language: What it is and how to teach it. Retrieved May 15, 2013, from http://www.nclrc.org/essentials/spe aking/goalsspeak.htm

Faculty of Arts. (2004). Undergraduate catalog. Nakhon Pathom, Thailand: Silpakorn University Press.

Goh, C. (2017). Teaching speaking in the language classroom. Singapore: SEAMEO Regional Language Centre.

Hancock, B. (2012). An Introduction to Qualitative Research. Retrieved December 2, 2014, from http://www.trentrdsu.org.uk/cms/uploads/Qualitative\%20Research

Huda, N. (2019). Learning and Teaching: Issues and Trends. Malang: IKIP Malang.

Ibrahim, M (2013). The Role of the English Department in Arab Universities. In Dahiyat \& Ibrahim (Eds.), Paper from the First Conference on the Problems of Teaching English Language and Literature at Arab Universities. The University of Jordan.

Kasim, U. (2003). Classroom Interaction in the English Department Speaking Class at the State University of Malang. Dissertation (Unpublished), Malang: PPS Universitas Negeri Malang.

Liu, M., \& Jackson, J. (2008). 'An exploration of Chinese EFL Learners' Unwillingness to Communicate and 
Foreign Language Anxiety. Modern Language Journal, 92, 71-86. https://doi.org/10.1111/j.1540-4781.2008.00687.x

Lucas, S. E. (2011). The Art of Public Speaking (7th ed.). Singapore: McGraw-Hill.

Mukattash, L. (1985). The Problem of Difficulty in Foreign Language Learning.

Musaddat, S. (2008). Penggunaan Strategi Pemodelan untuk Meningkatkan Keterampilan Berbicara Siswa Kelas 5 SD Mataram. Tesis (tidak diterbitkan). Malang: PPS IKIP Malang.

Nazara, S. (2011). Students' Perception of EFL Speaking Skill Development. Journal of English Language Teaching, 1(1), 28-43

Osborn, S., Osborn, M., \& Osborn, R. (2008). Public speaking guidebook. Boston: Pearson.

Patil, Z. N. (2008). Rethinking the Objectives of Teaching English in Asia. Asian EFL Journal, 10(4), $227-240$. Retrieved from http://www.asianefl-journal.com/December_18_zn.php

Tarquin, D. (2015). I can try it at least”: A strategy for Effective Inter-Class Oral Communication. English Teaching Forum, 33(1), 28-29.

Ur, P. (1996). A Course in Language Teaching Practice: and Theory. Cambridge: Cambridge University Press.

Yusuf, M., \& Sewoyo, S. (1997). The Evaluation of ELT at Trisakti University and Its Follow-up. In H. Column, T. Soedrajat \& G. Westaway (Eds.), Teaching English to Undergraduates in the Indonesian Context: Issues and Development. Bandung: ITB Press.

Zhang, S. (2009). The role of input, interaction, and output in the development of oral fluency. English Language Teaching, 2(4), 91-100. https://doi.org/10.5539/elt.v2n4p91

\section{Copyrights}

Copyright for this article is retained by the author, with first publication rights granted to the journal.

This is an open-access article distributed under the terms and conditions of the Creative Commons Attribution license (http://creativecommons.org/licenses/by/4.0/). 